УДК 330.4

A. Shkurykhin

\title{
VECTOR ERROR CORRECTION ESTIMATION OF THE UKRAINIAN SHADOW ECONOMY SHARE USING CURRENCY DEMAND APPROACH
}

\begin{abstract}
In order to avoid the limitations of the available empirical informal sector estimation methods and the problem with availability and coherence in input data, Currency demand approach to shadow economy estimation is extended by evaluating a Vector Error Correction model for the Ukrainian economy, using monthly monetary statistics data. The possible critique of the choice of exogenous factors determining the shadow economy and influencing the currency demand is avoided by modelling only the endogenous relationship between the cointegrating time series, namely the logarithm of currency in circulation and the deposit interest rate. The model is proven to be dynamically stable with theoretically justified values of the estimated coefficient and suitable for further analysis. Through historical decomposition, the upper-bound estimates of the size of Ukrainian shadow economy are obtained under the assumptions that all the currency demand unaffected by interest rate shocks is generated by informal economic activity; and that money velocity in the observed economy serves as an upper limit for the corresponding parameter of the informal sector in each time period. These estimates are found to be consistent with contemporary published studies of Ukrainian shadow economy. The proposed approach is considered useful for rapid informal sector estimations and provision of initial and boundary conditions for Multiple Causes Multiple Indicators and Computable General Equilibrium models.
\end{abstract}

Keywords: shadow economy, vector error correction, historical decomposition, currency demand estimation.

\section{JEL classification: C31, E41, O17}

Introduction and research problem. Shadow economy in the broadest definition is a set of economic activities, both legal and illegal, which are not accounted in the official gross domestic product statistics. Due to its inherent hidden nature, estimation of the shadow economy share is a demanding research question. Despite the difficulty, there exists a strong demand for a precise assessment from both the academia and policymakers, as the concept of shadow economy is closely related to the labor market, taxation, savings decisions, consumer preferences, and optimal macroeconomic policy, among other numerous issues. Over the two past decades, there has been a significant rise in the empirical studies of the unofficial sector through its traces in the recorded economy, both exploring the now-classical concepts and inventing the new methodology. However, all of the currently available methods are prone to critique of the assumptions about the relationship between hidden and official economy; still, their constant improvement and recombination lead to better results in both descriptive and predicting modeling, and methodological discussions encourage better understanding of the shadow economy as a worldwide phenomenon appearing in both developed and developing countries.

Resent publications analysis. The overall latest review of the available shadow economy estimation methodologies is presented in (Medina \& Schneider, 2018), while the assessment of the studies specific for Ukraine has been done in (Shumska \& Nezhyvenko, 2013) and (Dadashova \& Kladova, 2016). The techniques commonly employed are generally divided into direct and indirect methods, and the current academic focus seems to be shifted towards the indirect ones. The direct methods, namely the System of National Accounts Statistics discrepancy, survey studies of both households and firms' managers, and the estimation of the households' consumption-income (obtained from unrelated sources) gap, suffer seriously from specific requirements upon the availability and quality of the input data that is clearly not available for all the countries and all the necessary time frames. The indirect methods, based on more widespread statistics of electricity consumption, labor markets, firms' financial statements, and monetary data, gain more attention due to availability to use in all the coun- 
tries, including underdeveloped one, and aggregate the results using cluster analysis, predictive mean matching, and panel regression, among other available methods. From the point of input data quality, monetary indirect methods, such as currency demand approach, are often considered the "first-best" alternative to obtain baseline shadow economy estimations, later used for benchmarking or calibration purposes.

Unsolved parts of the problem. A general approach to the currency demand estimation is based on the early defining works by (Cagan, 1958) and (Tanzi, 1983) and is characterized by the econometric estimation of the money demand function, which is often considered to be loglinear in, respectively, currency in circulation and the representative interest rate. In order to separate the demand for informal economy transactions, factors theoretically contributing to development of shadow economy are added to the currency demand function, and if their influence corresponds to the expected direction and magnitude, the input of the additional factors is considered to be attributed to unaccounted economic activity. However, the choice of these additional factors will always be the weakest point of the setup, as it is virtually impossible to devise a comprehensible list of statistically significant factors with expected inference, available quality data, and validity against a cross-section of countries. In order to bypass the theoretical background discussion on shadow economy factors, as well as scarcity of data for many of the possible option, the use of "atheoretical" autoregression, and Vector Autoregression in particular, models is promising. As known from recent developments of money demand function estimations, such as (Bae \& De Jong, 2005), even in the simplest log-linear or log-log functional specification, the time series will most likely be cointegrated, justifying the use of Vector Error Correction models, which results in better descriptive and predictive power of the estimation.

Research goal and questions. The aim of this research is to employ the Vector Error Correction model to the Ukrainian data on currency demand and relevant interest rate, available with the highest frequency in order to estimate the share of the shadow economy of the official gross domestic product. As any exogenous factors allegedly explaining the informal economy's demand for cash are excluded from the analysis on purpose, the obtained estimate will be an upper-bound assessment of Ukrainian shadow economy. The main research question is whether reliable estimates can be obtained and how they correspond to other contemporary studies of
Ukrainian informal sector. The study is organized in the following way:

1) Data is collected, and the prerequisites of employing Vector Error Correction methodology are examined;

2) Validity and limitations of use of the estimated model are both assessed;

3) Upper-bound shadow economy share is evaluated and compared to similar studies.

Main findings. The data for the analysis is obtained from International Monetary Fund's International Financial Statistics database (International Monetary Fund, 2018), namely the indicators "Monetary, Central Bank Survey, Monetary Base, Currency In Circulation, Domestic Currency" and "Financial, Interest Rates, Deposit, Percent per annum", which at the date of retrieval are available with monthly frequency from December 2001 to February 2018. The Currency in Circulation series will act as the data for national currency demand, while the Interest Rate on Deposits is chosen as the interest rate variable most suited for the estimation of the currency demand function due to describing the opportunity costs of holding cash and thus directly influencing the households' decision about assets allocation. It is worth noting that other interest rates variables, such as lending rate, money market rate, or refinancing rate, in Ukrainian economy tend to differ significantly (sometimes for the magnitude of over $100 \%$ ) from the deposit rate, but as these rates are generally not available on the money market to households and firms, they are excluded from the analysis.

For estimation of the Vector Error Correction model, a modified Engle-Granger methodology is used, such as described in (Lukyanenko \& Horodnichenko, 2002) and (Lukyanenko \& Zhuk, 2013). The log-linear Vector Correction model is estimated as the series for domestic currency demand are transformed. The primary step of the data analysis is the check for cointegration prerequisites through stationarity assessment of the variables using Augmented Dickey-Fuller, Dickey-Fuller GLS, and Kwiatkowski-Phillips-Schmidt-Shin tests, which are described in (IHS Global Inc., 2017). The results are summarized in Table 1.

While the test results for the currency demand series are coherent and straightforward, the conclusion about deposit rate stationarity allows for some ambiguity. Stationarity may be assumed under the assumption that deposit rate follows an upward deterministic linear trend, which is statistically significant, but no economic intuition can be provided to explain it over the timespan being analyzed. Most importantly, in order to avoid spurious correlations, 
it is always a beneficial approach to assume nonstationarity if in doubt. Therefore, for this research purposes, given the results of the majority of the test, the deposit rate series is assumed non-stationary, as well as the currency demand, and this conclusion allows to employ the Vector Error Correction methodology.

Table 1. Results of stationarity tests (source: the author's calculations)

\begin{tabular}{|l|l|l|}
\hline \multicolumn{1}{|c|}{ Test } & \multicolumn{1}{|c|}{$\begin{array}{c}\text { Log Currency } \\
\text { Demand }\end{array}$} & \multicolumn{1}{c|}{$\begin{array}{c}\text { Deposit } \\
\text { Rate }\end{array}$} \\
\hline $\begin{array}{l}\text { ADF with no trend } \\
\text { or intercept }\end{array}$ & Non-stationary & Non-stationary \\
\hline ADF with intercept & Non-stationary & Non-stationary \\
\hline $\begin{array}{l}\text { ADF with trend and } \\
\text { intercept }\end{array}$ & Non-stationary & Stationary at 5\% \\
\hline DFGLS with intercept & Non-stationary & Non-stationary \\
\hline $\begin{array}{l}\text { DFGLS with trend } \\
\text { and intercept }\end{array}$ & Non-stationary & Stationary at 10\% \\
\hline KPSS with intercept & Non-stationary & Non-stationary \\
\hline $\begin{array}{l}\text { KPSS with trend and } \\
\text { intercept }\end{array}$ & Non-stationary & Non-stationary \\
\hline
\end{tabular}

Several tests can be employed to verify the cointegration long-term relationship between variables, but for the analyzed case of two variables (thus limiting the possible cointegration equations to one) it is sufficient to regress the currency demand against the deposit rate and study the residuals of the model for stationarity. If the residuals are stationary, it can be concluded that the linear combination of the two integrated series is stationary, and therefore the cointegration equation exists. The estimation output for the regression $\log$ Currency demand $=\beta_{0}+\beta_{1} *$ Deposit rate $+\xi$ is summarized in Figure 1, while the results of residuals' stationarity tests are displayed in Table 2. It is worth noting that the sign of the coefficient for the deposit rate variable is positive, thus contradicting the theoretical expectations, but this discrepancy will be fixed during the Vector Error Correction estimation.

\begin{tabular}{|lrlll|}
\hline \multicolumn{1}{c}{ Variable } & Coefficient & Std. Error & t-Statistic & Prob. \\
\hline \hline \multicolumn{1}{c}{ C } & 23.69861 & 0.206044 & 115.0170 & 0.0000 \\
\multicolumn{1}{c}{ DEPOSIT_RATE } & 0.187349 & 0.020106 & 9.317858 & 0.0000 \\
\hline \hline R-squared & 0.310277 & Mean dependent var & 25.55670 \\
Adjusted R-squared & 0.306703 & S.D. dependent var & 0.869662 \\
S.E. of regression & 0.724119 & Akaike info criterion & 2.202481 \\
Sum squared resid & 101.1992 & Schwarz criterion & 2.236050 \\
Log likelihood & -212.7419 & Hannan-Quinn criter. & 2.216073 \\
F-statistic & 86.82249 & Durbin-Watson stat & 0.073493 \\
Prob(F-statistic) & 0.000000 & & \\
\hline \hline
\end{tabular}

Fig. 1. Summary of linear regression (source: the author's calculations, output from EViews 10 software)
Table 2. Results of residuals' stationarity tests (source: the author's calculations)

\begin{tabular}{|l|c|}
\hline \multicolumn{1}{|c|}{ Test } & $\begin{array}{c}\text { Residuals from linear } \\
\text { cointegration equation }\end{array}$ \\
\hline ADF with no trend or intercept & Stationary at $1 \%$ \\
\hline ADF with intercept & Stationary at 5\% \\
\hline ADF with trend and intercept & Stationary at $1 \%$ \\
\hline DFGLS with intercept & Stationary at 5\% \\
\hline DFGLS with trend and intercept & Stationary at 10\% \\
\hline KPSS with intercept & Stationary at 1\% \\
\hline KPSS with trend and intercept & Stationary at 5\% \\
\hline
\end{tabular}

With all the prerequisites checked, the Vector Error Correction model with one long-term cointegration equation and a simple $(1,1)$ lag structure (which was selected from multiple specifications for simplicit$y$ and the ease of coefficient interpretation without significant loss of descriptive power) is estimated. The long-term cointegration equation takes the form:

$$
\begin{gathered}
\log \text { Currencydemand }(-1)+0.128 * \text { Depositrate }(-1)- \\
-28.831=0,
\end{gathered}
$$

and the estimated coefficients imply that in the long run the increase in the deposit interest rate by 1 percentage point will result in currency demand decrease by $12,8 \%$, which is consistent with the theoretical expectations.

The error correction mechanism is described by the following two equations:

$D(\log$ Currency demand $)=-0.0096 *(\log$ Currency demand $(-1)+0.128 *$ Deposit rate $(-1)-28.831)-$ $-0.2889 * D(\log$ Currency demand $(-1))-0.0013 *$

$* D($ Deposit rate $(-1))$, and

$D($ Deposit rate $)=-0.0252 *(\log$ Currency demand $(-1)+$ $+0.128 *$ Deposit rate $(-1)-28.831)-1.7651 * D(\log$ Currency demand $(-1))+0.1769 * D($ Deposit rate $(-1))$.

Both long-run adjustment coefficients are statistically different from zero (t-statistics are displayed in Figure 2), negative and less than unity in absolute value, which makes the model stable in dynamics (Lukyanenko \& Horodnichenko, 2002). Their estimated values suggest that the speed of return to the long-term equilibrium between the currency demand and interest rate is moderate: only $0.96 \%$ of the deviation is momentarily corrected by the currency demand changes, and the responsiveness of the deposit rate is $2.52 \%$ within one time period. With such low estimated responsiveness rates, the model should be used to make long-term conclusions only, as the results in the short run will be practically unobservable.

\begin{tabular}{ccc|}
\hline \hline Error Correction: & D(LOG_CU... & D(DEPOSIT... \\
\hline \hline \multirow{2}{*}{ CointEq1 } & -0.009593 & -0.025218 \\
& $(0.00111)$ & $(0.01531)$ \\
& {$[-8.63847]$} & {$[-2.71405]$} \\
\hline
\end{tabular}

Fig. 2. Adjustment coefficients in the VECM model (source: the author's calculations, output from EViews 10 software) 
Fig. 3. Historical decomposition of currency demand response to deposit rate shock, December 2001 - February 2018 (source: the author's calculations, output from EViews 10 software)

In order to justify the magnitude of response of currency demand to deposit rate changes, historical decomposition is used. Historical decomposition analysis is similar to the dispersion decomposition analysis, but it gives the percentage deviation of the variable of interest from the unconditional mean in response to structural innovation in the explanatory variable (Foroni, 2014) and not the percentage of variation. The percentage of deviation from the mean in the adopted analytic framework can be considered as a proxy for changes in currency demand explained by the asset allocation decisions of economic agents, and the remaining deviation may be possibly attributed to the shadow economic activities. Thus, unity minus the obtained percentage deviation can be interpreted as the upper boundary for the shadow economy's demand for cash, assuming that money velocity in the shadow economy equals to the corresponding velocity in observed economy in each period. Although this assumption may be considered unrealistic by the scholars studying developed countries (some critique is available in (Medina \& Schneider, 2018) and (Ardizzi, Petraglia, Piacenza, \& Turati, 2011)), it is perfectly suitable for the presented analysis. The shadow economy in Ukraine is among the most extensive and institutionally developed in the world, and thus the money velocity of the observed economy appears to be a decent upper-bound approximation of the shadow economic counterpart.

As noted previously, the estimated model is of little usability for a short-term analysis due to the slow responsiveness of the variables to the long-term stationary equilibrium alongside high persistence observed

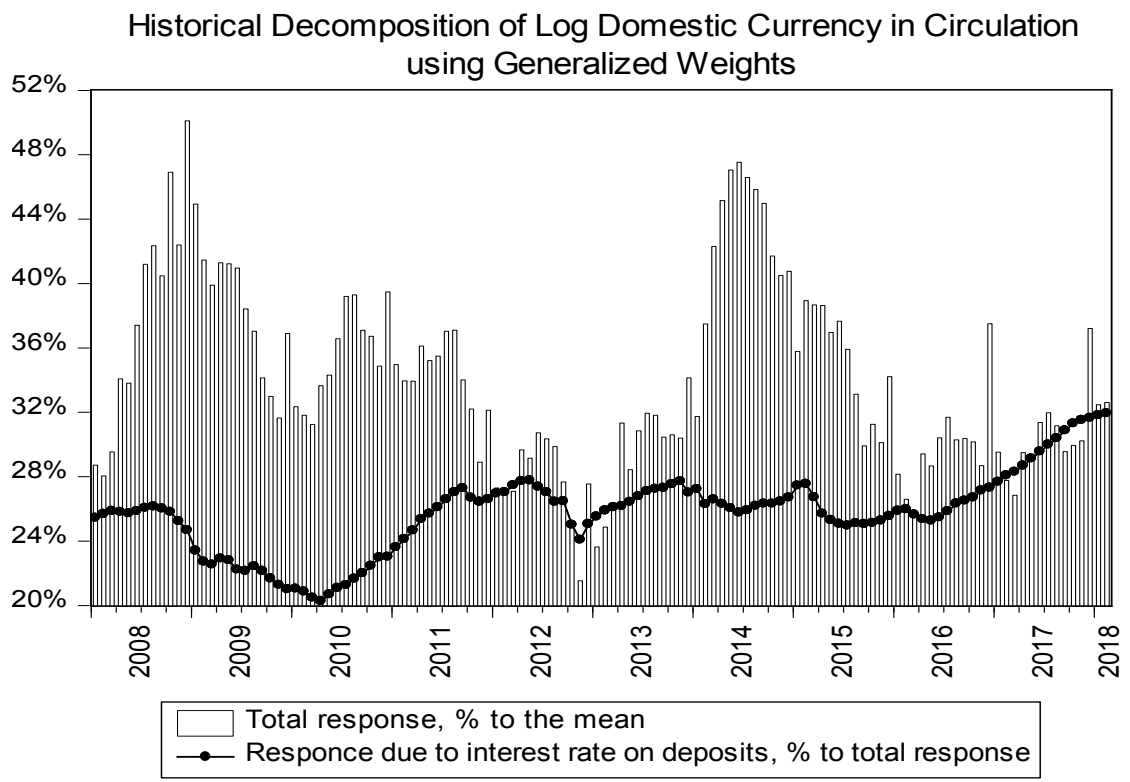

Fig. 4. Historical decomposition of currency demand response to deposit rate shock, January 2008 - February 2018

(source: the author's calculations, output from EViews 10 software) 


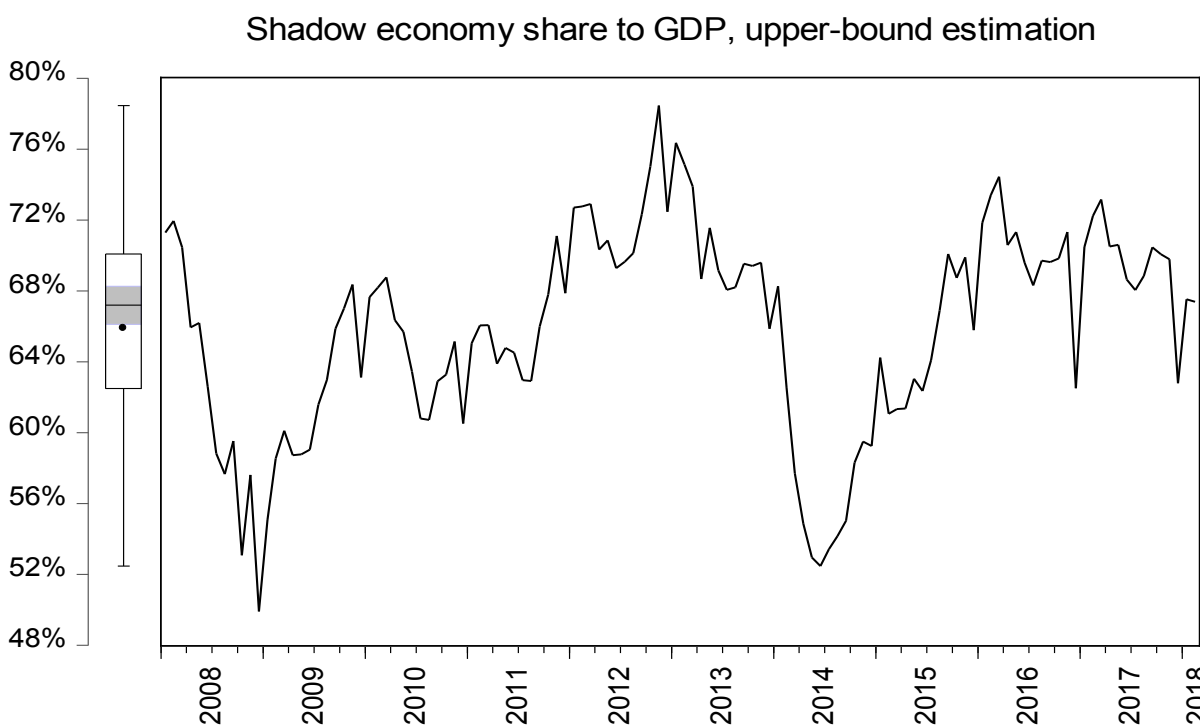

Fig. 5. Ukrainian shadow economy share (source: the author's calculations, output from EViews 10 software)

of the inflation targeting by the National Bank leading to growing importance of the interest rate channel of monetary policy and to deregulation in business environment (reflected in better Doing Business Index position) and the structural reforms (i. e. in public procurement and oil and gas industry) leading to the contraction in shadow economy.

Therefore, the upper-bound estimate of the Ukrainian shadow economy, using currency demand approach for monthly data between January 2008 and February 2018, is depicted in Figure 5, and the descriptive statistics are summarized in Figure 6. It is worth noting that the estimated numbers are following the data provided in (Medina \& Schneider, 2018), estimating the shadow economy share between $36.35 \%$ and $57 \%$ with an average of $44.8 \%$; and in (Ministry of Economic Development and Trade of Ukraine, 2018), providing the figures of $38 \%, 35 \%$ and $33 \%$ for the first three quarters of 2017 .

\begin{tabular}{|ll|}
\hline Mean & 0.658910 \\
Median & 0.671959 \\
Maximum & 0.784610 \\
Mnimum & 0.498993 \\
Std. Dev. & 0.057824 \\
\hline
\end{tabular}

Fig. 6. Descriptive statistics of shadow economy share estimation (source: author's calculations, output from EViews 10 software)

Conclusions and further research proposals. The use of Vector Error Correction modelling and historical decomposition has been proven useful in obtaining the upper-bound estimates of the Ukrainian shadow economy, which are consisted with contemporary studies of the subject and demonstrate an expected downward trend starting in 2015, reflecting the recent Ukrainian economic developments. The main theoretical advantage of this approach is the absence of reliance on the structural relationship between the factors determining the shadow economy and the currency demand. The main practical outcome of the method proposed comes from it being based on the monthly data published within two months from the end of the period, thus allowing for rapid estimation within a more frequent monthly time frame than the most common quarterly or yearly assessments. The limitations of the proposed approach arise from the assumption about the money velocity in the official economy being the upper limit of the money velocity in the informal sector; attributing all the currency demand unaffected by interest rate shocks to hidden economy; ignoring the US dollar cash circulation and barter transactions within the economy. By explicitly addressing the beforementioned limitation, a more accurate estimation (without the "upper-bound" covenant) should be obtained, and this issue is planned to be accompanied into future research. The results are of beneficiary use to researchers and policymakers for creating quick estimations before the National Accounts data is available, as well as for calibrating the Multiple Causes - Multiple Indicators models similar to described in (Dell'Anno, 2003) and (Schneider \& Buehn, 2016), and Computable General Equilibrium models similar to (Shkurykhin, 2016) 


\section{References}

1. Ardizzi, G., Petraglia, C., Piacenza, M., \& Turati, G. (2011). Measuring the Underground Economy with the Currency Demand Approach.

2. Bae, Y., \& De Jong, R. (2005). Money Demand Function Estimation by Nonlinear Cointegration. Ohio State University.

3. Cagan, P. (1958). The Demand for Currency Relative to Total Money Supply. Journal of Political Economy, 66, 303-328.

4. Dadashova, P., \& Kladova, M. (2016). Shadow Economy Impact on Economic Security of Ukraine. Effective Economics, 11

5. Dell'Anno, R. (2003). Estimating the Shadow Economy in Italy: a Structural Equation Approach. University of Aarhus, Working Paper No. 2003-07.

6. Foroni, C. (2014). A Primer of Structural VARs. Retrieved from Universitetet i Oslo: http://www.uio.no/studier/emner/sv/oeko nomi/ECON4160/h14/teaching-material/svar_lecturenotes.pdf.

7. IHS Global Inc. (2017, 10 25). Retrieved from EViews 10 Help Topics: http://www.eviews.com/help/helpintro.html.

8. International Monetary Fund. (2018, 04 25). International Financial Statistics. Retrieved from http://data.imf.org.

9. Lukianenko, I. G., \& Horodnichenko, Y. O. (2002). Modern Econometric Methods in Finance. Kyiv: Litera.
10. Lukianenko, I. G., \& Zhuk, V. M. (2013). Time Series Analysis. Part 2: Estimation of VAR and VECM models using E.Views 6.0. Kyiv: NaUKMA, AgrarMediaGroup.

11. Medina, L., \& Schneider, F. (2018). Shadow Economies Around the World: What Did We Learn Over the Last 20 Years? IMF Working Paper WP/18/17.

12. Ministry of Economic Development and Trade of Ukraine. (2018). Main Tendencies of Shadow Economy in Ukraine. Kyiv: MERT.

13. Schneider, F., \& Buehn, A. (2016). Estimating the Size of the Shadow Economy: Methods, Problems and Open Questions. IZA DP No. 9820.

14. Shkurykhin, A. (2016). Shadow Labor Market Analysis Within Computable General Equilibrium Model of Ukrainian Economy. Scientific Papers NaUKMA. Economics.

15. Shumska, S., \& Nezhyvenko, O. (2013). Shadow economy in Ukraine: methodology and evaluation. Current Economic Problems, 10, 74-83.

16. Tanzi, V. (1983). The Underground Economy of the United States: Annual Estimates 1930-1980. IMF Staff Papers, 30 (2), 283-305.

Шкурихін А. О.

\section{ОЦІНКА РІВНЯ ТІНЬОВОЇ ЕКОНОМІКИ УКРАЇНИ ЗА ПОПИТОМ НА ГОТІВКУ В МОДЕЛІ КОРИГУВАННЯ ПОМИЛКИ}

3 метою уникнення обмежень доступних емпіричних методів оцінки неформального сектору та проблеми наявності й узгодженості вхідних даних, підхід до вивчення тіньової економіки через попит на готівку розширено за допомогою використання векторної моделі коригування помилки, обчисленої для української економіки на основі місячних даних монетарної статистики. Задля уникнення критики вибору екзогенних факторів, які одночасно визначають обсяг тіньової економіки та впливають на попит на готівку, змодельовано виключно ендогенний зв 'язок між коінтегрованими часовими рядами логарифму обсягу готівки в обігу та відсоткової ставки за депозитами. Продемонстровано динамічну стабільність і придатність моделі для подальшого аналізу, а також відповідність очінених коефічієнтів теоретично обтрунтованим значенням. Із використанням історичної декомпозиції визначено верхню межу частки тіньової економіки в Україні за припущень, щуо весь попит на готівку, не зумовлений змінами відсоткової ставки, створюється неформальним сектором, та шо швидкість обертання грошей у офіиійній економіці є верхньою оцінкою відповідного параметра тіньової економіки у кожному з періодів. Отримані оцінки тіньової економіки відповідають значенням з опублікованих досліджень. Запропонований підхід визнано корисним для швидкого оцінювання частки тіньової економіки, а також для одержання початкових і граничних умов при створенні багатоіндикаторних моделей латентної змінної та моделей загальної рівноваги.

Ключові слова: тіньова економіка, модель коригування помилки, історична декомпозиція, попит на готівку. 